\title{
STUDI PERLAKUAN REAKSI ISOMERISASI 3-CARENE MENJADI 4-CARENE MENGGUNAKAN KATALIS NATRIUM-O-KLOROTOLUENA
}

\author{
Baiq Nisfi Hidayati, Tatang Shabur Julianto, Dwiarso Rubiyanto \\ Program Studi Ilmu Kimia, Fakultas Matematika dan Ilmu Pengetahuan Alam \\ Universitas Islam Indonesia \\ lalenisfi@gmail.com
}

\section{INTISARI}

Telah dilakukan penelitian tentang isomerisasi 3-carene menjadi 4-carene menggunakan katalis natrium-o-klorotoluena dengan perlakuan yang berbeda dari perlakuan sebelumnya yaitu dilakukan pembuatan katalis natrium-o-klorotoluena dan direfluks pada temperatur $250{ }^{\circ} \mathrm{C}$ selama 12 jam. Selanjutnya ditambahkan 3-carene dan di refluks kembali pada temperatur $170{ }^{\circ} \mathrm{C}$ selama 4 jam.

Hasil penelitian menunjukkan bahwa menggunakan perlakuan yang berbeda (katalis dan reaktan tidak dicampur) dari perlakuan sebelumnya (katalis dan reaktan dicampur) tidak dapat terbentuk katalis natrium-o-klorotoulena terhadap isomerisasi 3carene menjadi 4-carene. Hal ini disebabkan karena tidak terbentuknya katalis natrium-oklorotoluena dan proses isomerisasinya tidak bereaksi sempurna sehingga tidak diperoleh senyawa 4-carene melainkan diperoleh senyawa 3-carene, $\beta$-pinene dan pelarut.

Kata kunci: 3-carene, xylene, katalis natrium-o-klorotoluena, refluks, temperatur, variasi metode

\section{PENDAHULUAN}

Indonesia termasuk salah satu Negara penghasil minyak terpentin. Minyak terpentin sering disebut dengan spirits of turpentine berupa cairan yang mudah menguap, berasal dari hasil penyulingan getah jenis pohon yang tergolong dalam getah pinus. Di indonesia jenis pohon pinus penghasil minyak terpentin hampir seluruhnya berasal dari pinus merkusi (Sastrohamidjojo, 2004).

Komponen utama dari minyak terpentin adalah $\alpha$-pinene. Dimana $\alpha$-pinene sering digunakan sebagai bahan sintesis senyawa organik. Selain $\alpha$-pinene terdapat juga 3-carene. Salah satu upaya pengembangan 3-carene adalah dengan pengkonversian sebagian dari 3-carene menjadi 4-carene.

Metode isomerisasi 3-carene menjadi 4-carene sendiri telah dikembangkan dari penelitian sebelumnya. Pada penelitian sebelumnya dapat diketahui bahwa 3-carene dapat disintesis menghasilkan 4-carene dengan bantuan katalis natrium-oklorotoluena. Dimana senyawa 4carene yang dihasilkan kedepannya dapat digunakan dalam jalur sintesis untuk memperoleh senyawa lain yaitu menthol dan isolimonen.

Metode isomerisasi merupakan penggunakan basa sebagai katalis dan media pendukung yang sesuai. Media pendukung ini diharapkan 
mampu memberikan alternatif metode lainnya, sehingga hasil yang diperoleh dapat lebih baik dan penggunaan katalis akan lebih efisien.

Untuk memperoleh senyawa 4-carene, peneliti melakukan isomerisasi turunan senyawa 3carene menjadi 4-carene dengan variasi perlakuan yang berbeda dari peneilitian sebelumnya. Perlakuan yang berbeda dalam penelitian adalah tidak dilakukannya pencampuran secara bersama-sama antara katalis dan reaktan. Hal ini bertujuan untuk mengetahui dengan perlakuan yang berbeda (katalis dan reaktan tidak di campur) dapat menunjukkan hasil maksimal dalam pembuatan katalis terhadap reaksi isomerisasi 3-carene menjadi 4carene dan menghasilkan 4-carene dengan kualitas yang baik. Alternatif yang diusulkan peneliti merupakan suatu langkah atau cara yang digunakan dalam reaksi isomerisasi 3-carene menjadi 4-carene sehingga menghasilkan senyawa 4-carene dengan kualitas yang baik.

Keberhasilan penelitian ini dapat memberikan inovasi baru dalam memproduksi turunan terpenoid yang lebih berharga dari senyawa awal 3-carene dengan metode isomerisasi menggunakan katalis yang lebih efektif dan ekonomis sehingga dapat dilakukan dalam skala besar.

\section{METODE PENELITIAN}

\section{Bahan}

3-carene merck Sigma Aldrich, Xylene merck J.T. Baker, Oklorotoluena merck Schuchardt OHG dan Natrium merck Sigma Aldrich

\begin{abstract}
Alat
Satu set alat gelas, Seperangkat alat refluks, Termometer, Magnetic stirer, Penangas air dan GC-MS tipe QP-2010S Shimadzu.
\end{abstract}

\section{Prosedur Penelitan}

Pada penelitian ini, prosedur penelitian dimulai dengan membuat katalis natrium-o-klorotoluena, dengan cara sebagai berikut:

Pembuatan katalis natrium-oklorotoluena dibuat dengan cara mengambil $0,3 \mathrm{~mL}$ o-klorotoluena, $10 \mathrm{~mL}$ xylene bersama 0,3 gram natrium dimasukkan kedalam labu alas bulat leher dua $250 \mathrm{~mL}$ kemudian dimasukkan magnetic stirer sebagai pengaduk. Selanjutnya campuran direfluks dalam penangas minyak pada temperatur $250{ }^{\circ} \mathrm{C}$ selama $12 \mathrm{jam}$. Setelah proses refluks selesai, katalis yang dihasilkan di diamkan di dalam labu hingga dingin.

Selanjutnya dilakukan isomerisasi 3-carene menjadi 4carene dengan langkah sebagai berikut :

Setelah 12 jam alat dimatikan dan didinginkan. Selanjutnya ditambahkan $10 \mathrm{~mL}$ 3-carene. Refluks kembali dilakukan selama 4 jam dengan temperatur $170^{\circ} \mathrm{C}$. Hal 
ini bertujuan agar reaktan dan katalis yang terbentuk bercampur dan menghasilkan produk yang diinginkan. Setelah proses refluks, larutan campuran didinginkan dan selanjutnya dianalisis menggunakan GC-MS.

\section{Analisis larutan hasil dengan Gas Chromatography-Mass Spectroscopy (GC-MS).}

Dimana larutan hasil yang diperoleh kemudian dianalisis menggunakan GC-MS tipe QP2010S Shimadzu untuk mengetahui dan menentukan jumlah 3-carene yang terisomerisasi menjadi 4carene.

\section{HASIL DAN PEMBAHASAN}

Hasil dari isomerisasi 3carene dengan menggunakan katalis natrium-o-klorotoluena dengan menggunakan perlakuan yang berbeda yaitu katalis tidak dicampur bersamaan dengan reaktan. Penelitian ini bertujuan untuk mempelajari dan mengetahui dengan perlakuan yang berbeda dari peneliti sebelumnya dapat menunjukkan hasil maksimal dalam pembuatan katalis terhadap reaksi isomerisasi 3-carene menjadi 4-carene dan menghasilkan 4-carene dengan kualitas yang baik.

Penelitian yang telah dilakukan Booth (1968), senyawa 3carene dapat dikonversi menjadi 4carene melalui sistem katalis yang terdiri dari komposisi dasar logam alkali atau dengan katalis hidrogenasi. Penemuan yang dihasilkanpun berhubungan dengan konversi 3-carene menjadi 4-carene, dimana 4-carene berguna untuk konversi turunan terpen paramonosiklik. Langkah yang dilakukan untuk mengkonversi 3-carene menjadi 4-carene yaitu dengan menggunakan katalis yang terdiri dari basa organik.

Konversi 3-carene menjadi 4carene memiliki sifat reversible sehingga terjadi kesetimbangan pada reaksi konversi 3-carene menjadi 4carene. Senyawa 4-carene ini bukan merupakan komponen minyak terpentin yang biasa digunakan sebagai bahan dasar pelapis cat, akan tetapi 4-carene ini digunakan untuk konversi lebih lanjut menjadi senyawa terpenoid yaitu menthol dan isolimonen. Senyawa 3-carene menjadi 4-carene dapat dikonversi dengan proses isomerisasi thermal.

Dimana isomerisasi thermal berfungsi sebagai pemutus ikatan rangkap pada senyawa 3-carene yaitu $C_{3}$, dengan terputusnya ikatan rangkap pada $\mathrm{C}_{3}$ akan terjadi perpindahan ikatan rangkap ke $\mathrm{C}_{4}$ sehingga akan menjadi 4-carene.

Pada penelitian ini peneliti melakukan perlakuan yang berbeda dari penelitian sebelumnya yakni dari perlakuan antara katalis dengan reaktan terlebih dahulu tidak dicampur secara bersama-sama. Hal ini bertujuan untuk dapat membuat katalis natrium-o-klorotoluena secara maksimal. 


\section{Pembuatan Katalis Natrium-o- klorotoluena}

Tahap pertama dalam proses isomerisasi 3-carene menjadi 4carene yaitu natrium, o-klorotoluena, xylene dan magnetic stirer dimasukkan kedalam labu alas bulat leher dua, selanjutnya direfluks terlebih dahulu selama 12 jam hingga temperatur mencapai $250{ }^{\circ} \mathrm{C}$. Natrium-o-klorotoluena berfungsi sebagai katalis basa kuat organik. Akan tetapi dalam penelitian ini katalis natrium-o-klorotoluena tidak terbentuk, hal ini disebabkan karena temperatur yang diinginkan terlalu tinggi yaitu temperatur mencapai $250^{\circ} \mathrm{C}$ sehingga menyebabkan oklorotoluena menguap dan yang tersisa hanya natrium. Sedangkan katalis yang dibutuhkan adalah katalis natrium-o-klorotoluena yakni dengan bereaksinya natrium dan oklorotoluena. Xylene berfungsi sebagai pelarut yang memiliki sifat non polar selain itu xylene memiliki kekuatan pelarutan yang baik dan laju penguapan yang rendah.

\section{Isomerisasi 3-carene menjadi 4- carene}

Setelah 12 jam alat dimatikan dan dilakukan penambahan 3-carene. Selanjutnya direfluks kembali selama 4 jam pada temperatur $170{ }^{\circ} \mathrm{C}$. Fungsi dari 3-carene yaitu sebagai bahan utama (reaktan) dalam reaksi isomerisasi yang menghasilkan 4carene. Namun setelah penambahan 3-carene, natrium yang tersisa mengendap sehingga 3-carene dengan pelarut tidak bereaksi dan tidak diperoleh 4-carene. Melainkan terdapat senyawa baru yaitu 3carene, $\beta$-pinene dan pelarut.

Proses refluks bertujuan untuk menyempurnakan reaksi sedangkan pemanasan pada temperatur $250{ }^{\circ} \mathrm{C}$ bertujuan untuk mengoptimalkan penguapan minyak dalam penangas minyak.

Dalam penelitian ini terdapat beberapa faktor yang dapat mempengaruhi hasil diantaranya adalah keterbatasan alat yang tersedia, sehingga mengakibatkan optimasi alat tidak sesuai dengan yang diinginkan. Seperti penelitian sebelumnya yang dilakukan oleh Booth (1968), bahwa reaksi dalam penangas minyak dilakukan pada temperatur $250{ }^{\circ} \mathrm{C}$. Namun pada percobaan ini suhu reaksi yang diperoleh tidak selalu konstan, seperti pada penelitian yang dilakukan hanya dapat mencapai suhu akhir maksimum $170{ }^{\circ} \mathrm{C}$ dengan waktu reaksi total adalah 16 jam sehingga hasil yang diinginkan tidak tercapai yaitu tidak terbentuknya katalis natrium-oklorotoluena dan tidak diperolehnya 4-carene dalam reaksi isomerisasi.

Selain disebabkan karena pengaruh temperatur, pengadukan yang dilakukan dengan magnetic stirer selama reaksi berlangsung juga tidak kalah penting. Pengadukan yang dilakukan bertujuan agar semua reaktan dapat bercampur dengan 
sempurna. Selain itu juga dapat disebabkan karena waktu refluks dalam pembentukan katalis yang terlalu lama yakni 12 jam maka diharapkan untuk penelitian selanjutnya waktu refluks sebaiknya dilakukan selama 5-8 jam hingga temperatur $250{ }^{\circ} \mathrm{C}$. Setelah proses refluks selesai larutan hasil didinginkan hingga dingin. Kemudian larutan hasil dianalisis dengan Gas Chromatography-Mass Spectroscopy (GC-MS).

\section{Analisis larutan hasil dengan Gas}

\section{Chromatography-Mass}

Spectroscopy (GC-MS)

Hasil analisis identifikasi dari larutan hasil kemudian dianalisis menggunakan GC-MS yang dilakukan dengan menginjeksikan cuplikan ke dalam ruang injeksi. Cuplikan kemudian dibawa oleh gas pembawa (fase gerak) yang berupa He melalui kolom untuk dipisahkan karena memiliki sifat inert (tidak bereaksi dengan cuplikan). Afinitas cuplikan terhadap fase cair menentukan berapa lama cuplikan ditahan. Di dalam kolom, fase diam akan menahan senyawa secara selektif berdasarkan sifat polarnonpolar dari senyawa tersebut berdasarkan sifat "like dissolve like" dan akan dialirkan ke detektor yang memberi sinyal untuk kemudian dapat diamati pada monitor. Senyawa-senyawa yang memiliki afinitas rendah (tidak suka) terhadap fase akan keluar dari kolom pertama.
Sedangkan senyawa-senyawa dengan afinitas besar (larut dengan baik) terhadap fase diam akan keluar dari kolom selanjutnya.

Dari hasil analisis sintesis senyawa 3-carene menjadi 4-carene dilakukan dengan membandingkan spektrum massa dari sampel dengan data spektrum massa dengan melihat indeks kemiripan spektrum senyawa yang diperoleh. Adapun hasil kromatogram dari sampel hasil analisis kromatogram gasspektrometri massa diperlihatkan pada gambar berikut ini:

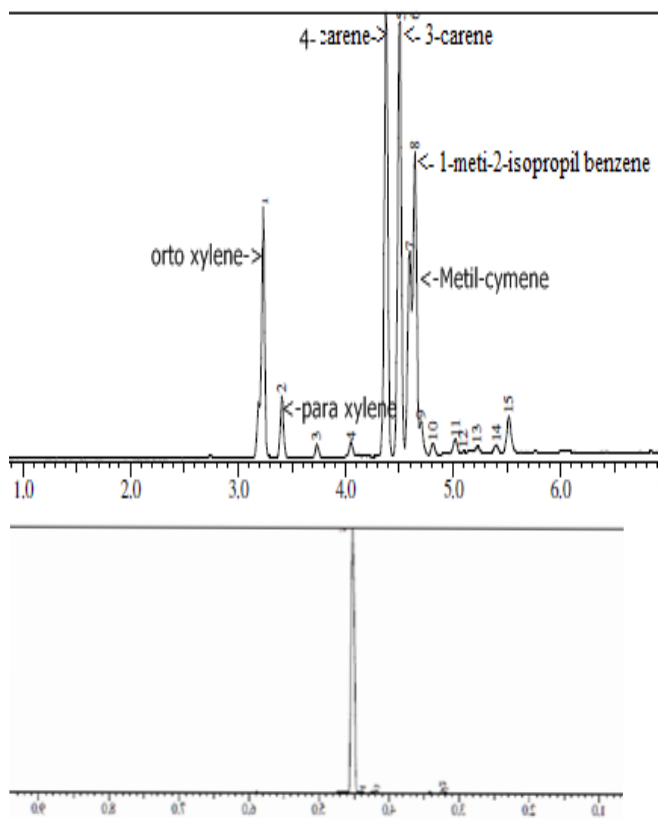

Gambar 1. Puncak Kromatogram hasil analisis sampel (a) pada larutan hasil dengan perlakuan sebelumnya (katalis dan reaktan di campur)dan (b) pada larutan hasil dengan perlakuan yang berbeda (katalis dan 
reaktan tidak di campur)

Gambar 1(a) menunjukkan bahwa pada puncak 1 dengan terdapat orto xylene, pada puncak 2 terdapat para xylene, pada puncak 7 terdapat metil cymene, pada puncak 8 terdapat 1-metil-2-isopropil benzena dan pada puncak 5 puncak yang paling tinggi terdapat 4-carene, pada puncak 6 juga puncak yang paling tinggi terdapat 3-carene. Pada percobaan pertama yaitu menggunakan perlakuan sebelumnya (dicampur), menunjukan bahwa puncak yang tertinggi adalah 3carene dan puncak 4-carene hal ini disebabkan proses isomerisasinya berereaksi sempurna sehingga diperoleh senyawa 4-carene yang optimum yaitu dengan perbandingan 49,8\%:50,2\% pada 3-carene dan 4carene. Penelitian ini menunjukkan bahwa hasil 4-carene yang diperoleh lebih besar dari pada penelitian sebelumnya.

Gambar 1(b) menunjukkan terdapat 5 puncak pada sampel dan diperoleh spektra yang mengidentifikasikan komponenkomponen senyawa yang terkandung di dalam sampel diantaranya adalah etil benzen $0,18 \%$ yang terdapat pada puncak 1 dengan waktu retensi 3,192 ; orto xylene $1,02 \%$ pada puncak 2 dengan waktu retensi 3,242; $\beta$-pinene $0,55 \%$ pada puncak 3 dengan waktu retensi 4,184; siklopropena $0,31 \%$ pada puncak 4 dengan waktu retensi 4,383; dan 3carene 97,94\% pada puncak 5 dengan waktu retensi 4,537. Pada percobaan kedua yaitu menggunakan perlakuan berbeda (katalis dan reaktan tidak dicampur), menunjukan bahwa puncak yang tertinggi adalah 3-carene, hal ini disebabkan karena tidak terbentuknya katalis natrium-oklorotoluena dan proses isomerisasinya tidak bereaksi sempurna sehingga tidak diperoleh senyawa 4-carene melainkan diperoleh senyawa 3-carene, $\beta$ pinene dan pelarut.

\section{Hasil data MS senyawa 3-carene menjadi 4-carene}

Berikut adalah spektum senyawa 3 -carene dan $\beta$-pinen pada sampel dengan perlakuan yang berbeda (katalis dan reaktan tidak dicampur):

\section{a. $\beta$-Pinen

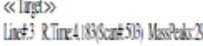

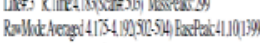

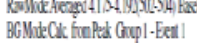 \\ $101-3$

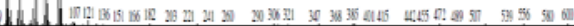

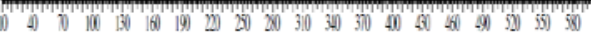 \\ Gambar 9. Spektra MS $\beta$-Pinen \\ Spektra massa $\beta$-Pinen yang ditunjukkan pada sampel dengan waktu retensi 3,184 menit yang terdapat pada puncak 3 dan luas area 0,55\% serta memiliki rumus molekul $\mathrm{C}_{10} \mathrm{H}_{16}$ dan ion molekul 93 dengan tingkat kemiripan 41 .}

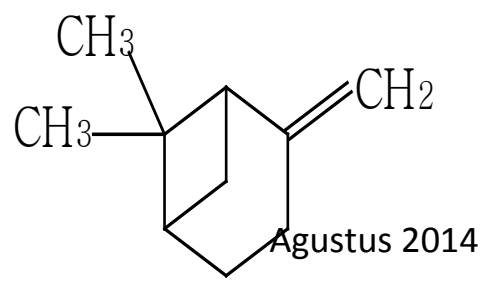


Gambar 10. Strukur $\beta$-pinene Senyawa ini merupakan kandungan minyak terpentin mengandung $\beta$-pinene sekitar 30\% dan memiliki titik didih $164{ }^{\circ} \mathrm{C}-166$ ${ }^{\circ} \mathrm{C}$. Aplikasi $\beta$-pinene sebagai bahan baku di dalam industri, telah menghasilkan berbagai rempahrempah dan vitamin $A$, vitamin $E$, dan lain-lain.

\section{b. 3-Carene}

«Tingt》

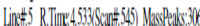

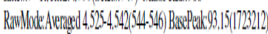

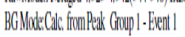

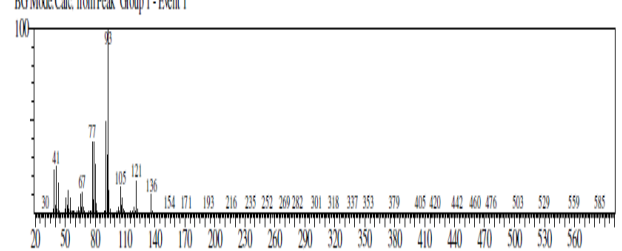

Gambar 11. Spektra MS 3-Carene

Spektra massa 3-carene yang ditunjukkan pada sampel dengan waktu retensi 4,537 menit yang terdapat pada puncak 5 dan luas area 97,94\% serta memiliki rumus molekul $\mathrm{C}_{10} \mathrm{H}_{16}$ dan ion molekul 136 dengan tingkat kemiripan 93.

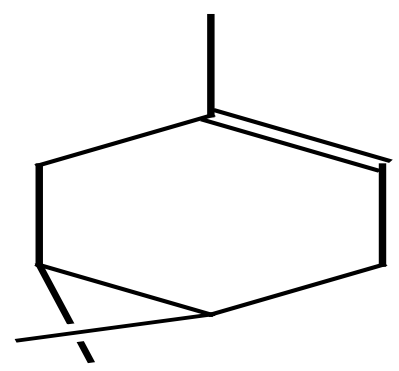

Gambar 12. Struktur 3-Carene

Senyawa 3-carene ini merupakan turunan dari senyawa terpenoid. Senyawa 3-carene memiliki bau manis dan tajam serta tidak larut dalam air tetapi larut dengan lemak dan minyak. Senyawa ini memiliki titik didih sekitar 168$169^{\circ} \mathrm{C}$.

\section{KESIMPULAN}

Hasil penelitian yang telah dilakukan maka dapat disimpulkan bahwa menggunakan perlakuan yang berbeda (katalis dan reaktan tidak di campur) dari perlakuan sebelumnya (katalis dan reaktan dicampur) tidak dapat terbentuk katalis natrium-oklorotoulena terhadap reaksi isomerisasi 3-carene menjadi 4carene. Hal ini disebabkan karena tidak terbentuknya katalis natrium-oklorotoluena dan proses isomerisasinya tidak bereaksi sempurna sehingga tidak diperoleh senyawa 4-carene melainkan diperoleh senyawa 3-carene dan $\beta$ pinene.

\section{UCAPAN TERIMAKASIH}

Penulis mengucapkan terima kasih kepada Bapak Tatang Shabur Julianto, M.Si., dan Bapak Dwiarso Rubiyanto, M.Si., yang telah memberikan kesempatan dan bimbingannya kepada kami untuk menyelesaikan penelitian ini, dan terima kasih kepada teman-teman yang telah membantu dalam penelitian ini. 


\section{DAFTAR PUSTAKA}

Anif, M.U., 2011, Kajian Kualitas dan Hasil Pengolahan Biodiesel Nyamplung (Colophyllum inophyllum) Pada Variasi Metode Ekstraksi, Metode Degumming Dan Konsentrasi Metanol, Universitas Jenderal Soedirman, Purwokerto.

Agusta, A., 2000, Minyak Atsiri Tumbuhan Tropika Indonesia, Penerbit ITB, Bandung.

Booth, A.B, Jekyii Island, Ga., assignor to Hercules Incorporated, Wilmington, Del., a corporation of Delaware., 1968, Isomerization of 3-Carene to 4Carene and Further Conversion of 4-Carene,(Cl.260-675.5).

Fatimah., 2010., Kimia Fisika, Universitas Islam indonesia, Yogyakarta.

Field, L.D., S. Sternhell, \& J.R. Kalman., 2008, Organic Structures from Spectra 4th Edition. Chichester: John Wiley and Sons,LTD.

Fessenden, R.J dan Fessenden,J.S., 1982, Kimia Organik. Edisi Ketiga. Jilid 2, Erlangga.

Fessenden, R .J dan Fessenden, J.S., 1986, Kimia Organik. Edisi Ketiga. Jilid 2, Erlangga.

Harborne, J.B., (1987), Metode Fitokimia, Penerbit ITB, Bandung.

Harvey, D., 2000, Modern Analytical Chemistry, McGraw-Hill, New York.

Herbert, R.B., 1995, Biosynthesis of Secondary Metabolites, 2nd edition,. Chapman and Hall, New York.

Khopkar., 2002, Basic Concept of Analytical Chemistry,diterjemahkan oleh Sapto Raharjo A., Penerbit Universitas Indonesia, Jakarta.

Rubiyanto, D., 2006, Kromatografi, Universitas Islam Indonesia, Yogyakarta.

Sastrohamidjojo, H., 1996, Sintesis Bahan alam, Cetakan ke-1, Liberty, Yogyakarta.

Sastrohamidjojo, H., 2004, Kimia Minyak Atsiri, Liberty, Yogyakarta.

Sastrohamidjojo, H., 2007, Kromatografi, Gadjah Mada University Press, Yogyakarta.

Sanshiro, K. Ed., 1997, Synthesis of Organometallic Compounds: A Practical Guide.

Santoso, H. Kristianto, I. dan Setyadi, A., 2013, Pembuatan Biodiesel Menggunakan Katalis Basa Heterogen Berbahan Dasar Kulit Telur, Lembaga Penelitian dan Pengabdian kepada Masyarakat, UKP.

Svehla, G., 1985, Analisis Anorganik Kualitatif Makro dan Semimakro, Edisi kelima, Bagian I, Kalman Media FMIPA ITS, Surabaya.

Tarun, K. Panda, Michael T. Gamer, and Peter W. Roesky., 2003, An Improved Synthesis of Sodium and Potassium Cyclopentadienide Organometallics, 22, 877-878. 